\title{
To Form Children Health Behaviour During the Covid-19 Pandemic: Teacher's Strategy and Obstacle
}

\author{
(Membentuk Perilaku Sehat Anak Semasa Pandemi Covid-19: Strategi dan Hambatan \\ pada Guru) \\ Dedy Surya \\ Department of Islamic Guidance and Counseling, Institut Agama Islam Negeri Langsa \\ dedysurya@iainlangsa.ac.id \\ *)corresponding author \\ First received: \\ 09 December 2020 \\ Revised: \\ 12 December 2020 \\ Final Accepted: \\ 29 December 2020
}

The Covid-19 pandemic is forcing everyone to change their behaviour to become more concerned about their health. This study aimed to illustrate the teachers' strategy and the obstacle in shaping health behaviours of children in school. By using a qualitative approach, the data was collected through in-depth interviews involving 9 participants (6 teachers and 3 parents). The results showed that to shape health behaviour, the teachers formed a conducive environment through a commitment with parents to implement a healthy lifestyle. This health behaviour campaign was carried out through creative means such as using stories and singing regularly and consistently. The teacher also engages other pupils to reprimand the child who committed the offence. This conducive environment will support the formation of health behaviours. Conversely, incompatible environments such as lack of facilities and the parent's inconsistency in at home intervening behaviour will damage the habits that have been established at school.

Keywords: behaviour formation, health behaviour, health protocols Perilaku $3 M$, the Covid-19 pandemic,

\begin{abstract}
Abstrak
Pandemi Covid-19 memaksa setiap orang untuk mengubah perilaku agar menjadi lebih peduli terhadap kesehatan. Penelitian ini bertujuan untuk melukiskan strategi dan hambatan guru dalam membentuk perilaku sehat anak di sekolah. Dengan menggunakan pendekatan kualitatif, data dikumpulkan melalui wawancara mendalam dengan melibatkan 6 partisipan dan 3 orang informan. Hasil penelitian menunjukkan bahwa perilaku sehat dibentuk dengan menciptakan lingkungan yang kondusif melalui Kerjasama orang tua dan melalui kegiatan yang kreatif secara konsisten dan teratur. Sementara lingkungan yang tidak kompetibel seperti kurangnya fasilitas di sekolah dan ketidakkonsistenan orang tua di rumah untuk membentuk perilaku akan menghancurkan kebiasaan di sekolah.
\end{abstract}

Kata Kunci: pembentukan perilaku, perilaku sehat, protokol kesehatan, Perilaku 3M, pandemic Covid-19

\section{INTRODUCTION}

After being announced as a worldwide pandemic, SARS-CoV 2-well known as Coronavirus Disease 2019 (Covid-19)- continues to have quite severe effects in many walks of life. (Rathi \& Kumar, 2020) . The spread has a massive impact, attacking the health sector and economy, but also has 
an impact on the field of education, (De, 2020), including Indonesia.

World Health Organization (WHO) reports that the virus is spreading fast. The virus moves from one human to another through droplet transmission and direct physical contact (World Health Organization, 2020a). That is, to prevent the spread of this virus, interhuman contact should be minimized wherever possible. Besides, the virus also spreads very quickly. Since the first cases found in Indonesia in early March 2020 (Nuraini, 2020) to the end of November 2020, there have 538.883 cases been reported (Okenews, 2020). It means that there are additional 59,876 new cases each month.

In the field of education, pandemics affect changes and adjustments to teaching and learning activities. Some of the adjustments made are learning from home with an online system (Pramana, 2020) or for regions where positively confirmed cases are relatively controlled can conduct direct learning by implementing strict health protocols. By the Indonesian government, prevention efforts through minimizing physical contact are formulated through the "Perilaku 3M", namely: 1) Mencuci tangan (Washing hand), 2) Menggunakan masker (Wearing mask), and 3) Menjaga jarak (Keeping distance) (Listina et al., 2020). This movement is massively campaigned through various information channels throughout Indonesia and targeted to all levels, including early childhood. In terms of preventing the spread of the virus, early childhood needs to get special attention. It was because children are a very vulnerable group to disease, considering their immunity is not as optimal as adults (Mardhianti, 2019). Furthermore, the pandemic also has implications for the declining quality of nutrition and health in children (Akseer et al., 2020).

For dealing with that, children are required to be able to modify their behaviour radically and quickly. As a vulnerable group, the effectiveness of changing children's behaviour seems to be competing with the growth of reactive rates of Covid-19 patients. In order to prevent this pandemic attack, creative adaptation becomes an alternative that can be taken to compensate for the transposition that occurs so that increasingly complex problems can also be resolved (Surya, 2018).

The study on the habituation of new behaviours in early childhood during pandemics has been conducted several times. Safitri and Harun (2020) reviewed the efforts made by early childhood educators in implementing a clean and healthy lifestyle during the pandemic. Tabi'in (2020) highlighted the habituation of healthy living behaviours in order to prevent the spread of the virus. Nugroho and Yulianto (2020), through their article, encouraged the establishment of a PAUD Sehat (healthy school) program that adheres to health protocols to reduce the impact of outbreaks. This study aims to find out the patterns of strategies carried out by teachers as well as the obstacles experienced in dealing with the adaptation of new normality in early childhood through habituation of behaviour. The health behaviours that are put forward as a new form of normality adaptation discussed are focused explicitly on the "Perilaku 3M".

\section{METHOD}

This research was conducted using a qualitative approach with a case-study research, namely dive into specific 
problems and contexts in depth through complex information in order to describe the unique problem variants of the selected locus (Creswell, 2013). This type of research was chosen because researchers wanted to comprehensively identify and explore strategies by kindergarten teachers for behavioural habituation of the "Perilaku $3 M "$. This research involved subjects that were directly related to the process of forming the "Perilaku 3M" at schools, namely students, teachers, and principals. In addition, to deepen the research findings, information from parents was needed.

The primary data of this study involved 6 teachers (AS, DT, RD, ST, SU, and $\mathrm{ZR}$ ) in Langsa, Aceh, Indonesia. Then, to enrich the study findings, the researchers also involved 3 parents of students (MA, NT, and RB). Research data collected through an in-depth interview to all research subjects between SeptemberOctober 2020. Furthermore, researchers conducted nonparticipant observations to confirm the findings of the interview. The collected data was then analysed by Miles and Huberman's (1994) techniques as described by through the stages of reducing the findings that have been collected, and presenting information and data for verification and withdrawal of conclusions.

\section{FINDINGS AND DISCUSSION}

The formation of the "Perilaku 3M" in early childhood is preceded from providing correct information on what a pandemic is. Most of the children know about Covid-19 from various sources of information. Public service advertisements that are regularly aired on television, information distributed through posters and banners, as well as leaflets that are widely distributed in the neighbourhood where they live, have provided them with sufficient information about Covid-19 and its prevention efforts. That is, children are cognitively already equipped with enough information about the virus as a new entity among them. A good understanding of this pandemic implies an understanding that the presence of the virus causes them not to be located or create crowds.

It has confirmed that Hernawati and Palapah (2011), stating that television becomes a mouthpiece of information for early childhood in shaping behaviour and character. This finding also reinforces the findings of Robinson et al. (2014), which prove the effectiveness of communication media to campaign for health behaviour.

Efforts to shape the behaviour of using masks are a challenge. To familiarize the masks, the headmaster made a regulation that on the way from home to school, parents are asked to wear masks on children. Arriving at school, the teacher replaced his mask with a face shield in front of the school gate. Active participation from parents is required to enforce these established regulations. However, the implementation did not go smoothly. The use of masks is considered more challenging to apply in early childhood, given the high activity of children's movements.

Furthermore, children feel that masks make it difficult for them to breathe. Therefore, the headmaster took the decision not to require the child to wear a mask. This strategy is not contrary to $\mathrm{WHO}$ recommendations that do not recommend the use of masks when exercising or doing high-intensity activities (World Health Organization, 2020b). Instead, the headmaster took the initiative to replace the mask with a face shield. To be more 
compatible with the children, the face shield used is also modified so that it is easier to use and not easily removed when children play. In addition to avoiding droplet transmission from others, a face shield is also useful to reduce the frequency of children touching $\mathrm{T}$-areas on the face. Face shield that will be used by children is prepared by the school and written the name of each child. The findings above show that engagement and cooperation between teachers and parents play a central role in shaping a child's behaviour. Habituation of new behaviours carried out in schools should also get a positive response from parents as the main actors at home. These findings reinforce previous studies that have shown that the role of parents and families is a significant predictor of behavioural formation (Falhatunnisa \& Santika, 2020; Prasanti \& Fitriani, 2018).

To teach handwashing behaviour, teachers implement several strategies. First, the teacher explained the behaviour of the virus that quickly moves through the touch of the hand. The explanation is done using easy-to-understand sentences and through stories. This pattern reinforces previous studies (Aisah, 2012; Hamdalah, 2013; Rachmayani et al., 2018) which refer to the effectiveness of using stories to promote the transformation of healthy living behaviours in children.

Second, children are taught to wash their hands using soap by giving examples of proper handwashing patterns to imitate. For children who seem to be reluctant to be actively involved in impersonation, teachers mentored directly. Sometimes, to ensure that the child is accustomed to the behaviour of washing hands with soap, the teacher tests by not giving soap. The kid asked, "Where is the soap, Ma'am?" This response indicates that the modelling that teachers give to children has effectively shaped new behaviours. It is due to the tendency of early childhood to imitate (Ismaniar \& Utoyo, 2020). Similarly, Nielsen \& Blank (2011) explained children's ability to replicate adult behaviour easily.

To support the distance-keeping campaign, the headmaster implemented learning with a shift system in turn. For each shift in one class, a maximum of 8 students are filled. In the classroom, repeated information to students causes them to get used to keeping their distance in the classroom. During the observation, it was seen that when approached by his friend, the children said, "Do not go near it, the virus will come." The unique thing was when children queued when they wanted to wash their hands. When a friend of his was standing in line at close range, the children shouted, "Stop! Two boxes, please." It means that the child wants his friend to keep his distance from him as far as two tile boxes measuring $60 \times 60 \mathrm{~cm}$.

Furthermore, when his friend's son did not obey the instructions, he complained to the teacher that there was a friend who did not want to stand as far as two boxes. Then, the teacher gave an affirmation with the word "Watch out the virus, dear!". On arrival, they immediately kept their distance. Another strategy used by teachers to remind students of crowding is to deliver instructions through singing. Another unique strategy that teachers use to remind children is to ask questions to other students such as, "Who does not wear a face shield? Who knows what the Covid19 is? What happens if we do not wear face shields?" The question is asked to get a response from his friend so that the child who broke the rules will immediately realize his mistake. It means that teachers 
use peer mentorship systems in early childhood to explain health protocols.

To conclude, the role of the headmaster as a leader is also crucial in the enforcement of discipline. The headmaster did not seem reluctant to reprimand anyone who did not comply with health protocols within the school area. The headmaster instructed the teachers to facilitate healthy living behaviours in the school area, such as sinks and soap. These findings reinforce research that mentions the strategy (Sudrajat et al., 2020), the leadership (Hadi, 2020), and the creativity (Khairuddin, 2020) that the headmaster has played a vital role in the process of behavioural adaptation during the pandemic. The headmaster's understanding of his responsibility to maintain health in the school environment has implications for the teacher's understanding of a healthy lifestyle. This good teacher's understanding affects the appearance of the good habits of the child.

The transformation of new behaviour is not an easy thing. Its implementation will always face various obstacles. Similarly, the implementation of the "Perilaku $3 M^{\prime}$ " also faces obstacles. Several things are obstacles to the implementation of this behaviour. The fundamental thing is the lack of facilities available. In the locus of the research, the obstacles arose due to limited handwashing facilities. This limitation causes children to have to wait in line for long to wash their hands, thus provoking their impatience and making the children rowdy. Another obstacle that arises is because there are still parents who do not believe in the coronavirus. The inequality of perception between teachers and parents has implications for the lack of adequate education from the family environment so that when at home, children do not apply $3 \mathrm{M}$ behaviour consistently. To add, their playmates at home are also not used to implementing health protocols properly. This accumulation of disturbances from their home environment damages well-formed habits. This study corroborates Sallis \& Owen's research (2015) that environmental factors they refer to as ecological models or which by Green (1980) is referred to as reinforcing factor is crucial in shaping health behaviour.

\section{CONCLUSION}

Conclusively, to shape health behaviour, the teachers formed a conducive environment through a commitment with parents to implement a healthy lifestyle. This health behaviour campaign was carried out through creative means such as using stories and singing regularly and consistently. The teacher also engages other pupils to reprimand the child who committed the offence. This conducive environment will support the formation of health behaviors. Conversely, incompatible environments such as lack of facilities and the parent's inconsistency in at home intervening behaviour will damage the habits that have been established at school. This study involved only 6 participants. Thus, the complexity of health behaviour formation will be more profound if it involves more participants and can give a more holistic draw.

\section{REFERENCES}

Aisah, I. (2012). Strategi penumbuhan perilaku prososial anak usia melalui metode bercerita (Studi kasus Pendidikan Anak Usia Dini (PAUD) Matahari RW X1V Kelurahan Citeureup Kecamatan Cimahi Utara Kabupaten Cimahi). 
EMPOWERMENT: Jurnal Ilmiah Program Studi Pendidikan Luar Sekolah, 1(2), 121-129. https://doi.org/10.22460/EMPOWERM ENT.V1I2P121-129.622

Akseer, N., Kandru, G., Keats, E. C., \& Bhutta, Z. A. (2020). COVID-19 pandemic and mitigation strategies: implications for maternal and child health and nutrition. The American Journal of Clinical Nutrition, 112(2), 251256.

https://doi.org/10.1093/ajcn/nqaa171

Creswell, J. W. (2013). Qualitative inquiry and research design: Choosing among five approaches. SAGE Publications.

De, S. (2020). Impacts of the Covid-19 pandemic on global education. In R. R. Nadikattu (Ed.), COVID-19 Pandemic update 2020 (pp. 84-94). Royal Book Publishing.

https://doi.org/https://doi.org/10.26524 /royal.37.6

Falhatunnisa, I., \& Santika, T. (2020). Persepsi keluarga tentang pentingnya pendidikan anak usia dini dalam pembentukan karakter. In Journal of Community Education (Vol. 1, Issue 1). https://doi.org/10.35706/JOCE.V1I1.385 6

Green, L. (1980). Health education planning: A diagnostic approach. Mayfield Pub Co.

Hadi, L. (2020). Kepemimpinan kepala sekolah dalam menghadapi pandemi Covid-19. Transformasi: Jurnal Studi Agama Islam, 13(2), 75-81. http://ejournal.stainupacitan.ac.id/inde x.php/Transformasi/article/view/117

Hamdalah, A. (2013). Efektivitas media cerita bergambar dan ular tangga dalam pendidikan kesehatan gigi dan mulut siswa SDN 2 Patrang
Kabupaten Jember. Jurnal Promkes, 1(2), 118-123.

Hernawati, R., \& Palapah, M. A. O. (2011). Televisi dalam kehidupan anak. Prosiding SNaPP: Sosial, Ekonomi Dan Humaniora, 2(1), 477-484. http://proceeding.unisba.ac.id/index.p $\mathrm{hp} /$ sosial/article/view/307

Ismaniar, I., \& Utoyo, S. (2020). "Mirror of Effect" dalam perkembangan perilaku anak pada masa pandemi Covid 19. Diklus: Jurnal Pendidikan Luar Sekolah, 4(2), 147-157. https://doi.org/10.21831/diklus.v4i2.324 29

Khairuddin, K. (2020). Kepemimpinan kepala sekolah di tengah pandemi Covid-19. Edukasi, 8(2), 171-183. http://ejournal.unisi.ac.id/index.php/ju dek/article/view/1161

Listina, O., Solikhati, D. I. K., \& Fatmah, I. S. (2020). Edukasi Corona Virus Disease19 (Covid-19) melalui penyebaran poster kepada masyarakat Kecamatan Slawi Kabupaten Tegal. JABI: Jurnal Abdimas Bhakti Indonesia, 1(2), $\quad$ 10-10. http://ojs.stikesbhamadaslawi.ac.id/ind ex.php/JABI/article/view/210

Mardhianti, R. (2019). Guru PAUD: Pendidikan Perilaku Hidup Bersih dan Sehat (PHBS) anak usia dini. IkraithAbdimas, 2(3), 133-141.

Miles, M. B., \& Huberman, A. M. (1994). Qualitative data analysis: An expanded sourcebook (2nd ed.). SAGE Publications.

Nielsen, M., \& Blank, C. (2011). Imitation in young children: When who gets copied is more important than what gets copied. Developmental Psychology, 47(4), 
1050-1053.

https://doi.org/10.1037/a0023866

Nugroho, I. H., \& Yulianto, D. (2020). Penerapan disiplin protokol kesehatan di era kenormalan baru pada dunia PAUD. Jurnal Al-Hikmah, 8(1), 150-156.

Nuraini, R. (2020). Kasus Covid-19 pertama, masyarakat jangan panik. https://indonesia.go.id/narasi/indonesi a-dalam-angka/ekonomi/kasus-covid19-pertama-masyarakat-jangan-panik

Okenews. (2020). Update Corona 30 November 2020: Positif 538.883 Orang, 450.518 Sembuh dan 16.945 Meninggal. Okenews.

https://nasional.okezone.com/read/202 0/11/30/337/2318902/update-corona-30november-2020-positif-538-883-orang450-518-sembuh-dan-16-945-

meninggal

Pramana, C. (2020). Pembelajaran Pendidikan Anak Usia Dini (PAUD) di masa pandemi Covid-19. Indonesian Journal of Early Childhood: Jurnal Dunia Anak Usia Dini, 2(2), 116-124. https://doi.org/10.35473/ijec.v2i2.557

Prasanti, D., \& Fitriani, D. R. (2018). Pembentukan karakter anak usia dini: Keluarga, sekolah, dan komunitas? (Studi kualitatif tentang pembentukan karakter anak usia dini melalui keluarga, sekolah, dan komunitas). Jurnal Obsesi: Jurnal Pendidikan Anak Usia Dini, 2(1), 13-19. https://doi.org/10.31004/obsesi.v2i1.2

Rachmayani, D., Kurniawati, Y., \& Lestari, S. (2018). Penerapan metode dongeng dalam meningkatkan pengetahuan dan perilaku menggosok gigi pada anak taman kanak-kanak. ELSE (Elementary School Education Journal): Jurnal Pendidikan Dan Pembelajaran
Sekolah Dasar, 2(2), 12-20. https://doi.org/10.30651/else.v2i2.1678

Rathi, A., \& Kumar, A. (2020). Effect of Covid 19 on various sectors. International Journal of Trade and Commerce-IIARTC, 9(1), 102-110. https://doi.org/10.46333/ijtc/9/1/14

Robinson, M. N., Tansil, K. A., Elder, R. W., Soler, R. E., Labre, M. P., Mercer, S. L., Eroglu, D., Baur, C., Lyon-Daniel, K., Fridinger, F., Sokler, L. A., Green, L. W., Miller, T., Dearing, J. W., Evans, W. D., Snyder, L. B., Kasisomayajula Viswanath, K., Beistle, D. M., Chervin, D. D., ... Rimer, B. K. (2014). Mass media health communication campaigns combined with healthrelated product distribution: A community guide systematic review. In American Journal of Preventive Medicine (Vol. 47, Issue 3, pp. 360-371). Elsevier Inc. https://doi.org/10.1016/j.amepre.2014.0 5.034

Safitri, H. I., \& Harun, H. (2020). Membiasakan pola hidup sehat dan bersih pada anak usia dini selama pandemi Covid-19. Jurnal Obsesi: Jurnal Pendidikan Anak Usia Dini, 5(1), 385.

https://doi.org/10.31004/obsesi.v5i1.542

Sallis, J. F., \& Owen, N. (2015). Ecological models of health behavior. In K. Glanz, B. K. Rimer, \& K. Viswanath (Eds.), Health behavior: Theory, research, and practice (5th ed., pp. 43-64). JosseyBass.

Sudrajat, C. J., Agustin, M., Kurniawati, L., \& Karsa, D. (2020). Strategi Kepala TK dalam meningkatkan mutu pendidikan pada masa pandemi Covid 19. Jurnal Obsesi: Jurnal Pendidikan 
Anak Usia Dini, 5(1), 508. World Health Organization. (2020a). https://doi.org/10.31004/obsesi.v5i1.582 Modes of transmission of virus causing

Surya, D. (2018). Pengembangan kreativitas berbasis kepribadian pada anak usia dini. Atfālunā: Journal of Islamic Early Childhood Education, 1(1), 30-35. https://doi.org/10.32505/atfaluna.v1i1.7 73

Tabi'in, A. (2020). Perilaku hidup bersih dan sehat (PHBS) pada anak usia dini sebagai upaya pencegahan Covid 19. JEA (Jurnal Edukasi AUD), 6(1), 58. https://doi.org/10.18592/jea.v6i1.3620 COVID-19: Implications for IPC precaution recommendations: Scientific brief. In World Health Organization.

https://www.who.int/docs/defaultsource/coronaviruse/situationreports/20200423-sitrep-94-covid19.pdf

World Health Organization. (2020b). People should NOT wear masks while exercising. https://www.youtube.com/watch?v=1_ AxGswGnno 